Acta vet. scand. 1961, 2, 375-398.

From Department of Biochemistry, Veterinary College of Norway, Oslo, Norway.

\title{
THE OCCURRENCE OF CONDITIONED AND SIMPLE COPPER DEFICIENCY IN CATTLE AND SHEEP IN SETESDALEN, A VALLEY IN THE SOUTHERN PART OF NORWAY
}

II

By

Gustav N. Havre and Olav Dynna

The occurrence of conditioned and simple copper deficiency in Setesdalen has been described in a previous paper by Havre, Dynna and Ender (1960). The conditioned form of copper deficiency was found scattered over various localities within this valley, in districts where grass and hay samples showed molybdenum levels higher than normal, i.e. levels above 3 p.p.m., besides a normal or slightly subnormal copper content. The occurrence of simple copper deficiency, however, was limited to one district only, where herbage analyses showed a normal molybdenum content associated with abnormally low copper values, i.e. values below 5 p.p.m. As stated in the first paper, Cunningham's "normal values" (1955) were used as a reference, as these values are also in good conformity with the results derived from our own investigations.

The clinical symptoms are described in detail, likewise the almost dramatically beneficial effect of copper treatment. The symptoms of either form of copper deficiency are much the same, with the exception of diarrhoea, which is only seen in connection with conditioned copper deficiency. This is in good agreement with observations made by other authors.

The fact that molybdenum is an important factor in the syndrome af conditioned copper deficiency in Setesdalen, was stated 
in the first paper. However, other conditioning factors might be present. Dick reported (1952 and 1953) that inorganic sulphur is a necessary conditioning factor besides molybdenum. It was decided, therefore, to submit the herbage material which was collected during 1958 to an analysis of sulphur, and to a general spectrographic analysis of all elements detectable by a direct arcing of grass ash.

Due to the fact that conditioned copper deficiency is seldom observed during stallfeeding, but is seen frequently at pasture with a tendency for the heaviest cases to occur late in the autumn, it was to be expected that the molybdenum content of the herbage could be subjected to seasonal variations. It was reasonable to suppose that the lowest molybdenum values were to be found early in the summer, when grass is mowed for hayproduction, whereas the highest molybdenum values were expected to be found during the late summer and the autumn. Field (1957) has in his studies on the seasonal variations of molybdenum and copper in herbage found an inverse relationship between molybdenum and copper by which levels of molybdenum increased during the summer, while the copper content decreased during the same interval.

The farming conditions in Setesdalen are well suited for a study of the seasonal herbage variations, as hay and grass comprise the main feeding used throughout the year. As it was thought that a closer study of the mineral variations in the herbage occurring during the pasture season would give valuable information with respect to the importance of the Mo/Cu-relationship in the copper deficiency syndrome, the following investigation was started. The discussion of the results obtained forms a main part of this paper.

\section{SEASONAL VARIATIONS OF MOLYBDENUM AND COPPER IN HERBAGE}

The investigation was carried out in accordance with the following plan: Six farms, scattered over the whole valley, were in 1959 selected for sampling. (See Table 1.) On farm no. 1, which was used as a control, copper deficiency has never been observed in any form. On farm no 2, cases of simple copper deficiency have been proved, and on the remaining four farms (nos. 3-6) conditioned copper deficiency was well known. Two 
of the farms (nos. 5 and 6 ) are not included in the material collected during 1958. One of the farms (no 3), has no cattle at present, but as analyses of grass and hay from this farm during the years 1957-1958 revealed extremely high molybdenum values, the farm was nevertheless included in the study, and samples were collected from two different fields of this farm.

All samples were taken with two to three weeks' interval from June the 2nd to October the 6th, i.e. about nine samples from every sampling field. The results of the analyses of molybdenum and copper are presented in Table 1.

Table 1 shows that the molybdenum content as well as the copper content were on the whole lower in 1959 than in the preceeding two years. The copper content was mainly found to be

Table 1.

Samples of grass collected in Setesdalen during the summer 1959. The analytical values are calculated in oven dried material.

\begin{tabular}{rlcccccc}
\hline J.no. & $\begin{array}{c}\text { Farm no. \& } \\
\text { botanical composition }\end{array}$ & $\begin{array}{c}\text { Date of } \\
\text { sampling }\end{array}$ & $\begin{array}{c}\text { Dry matter } \\
\text { per cent }\end{array}$ & $\begin{array}{c}\text { Ash } \\
\text { per cent }\end{array}$ & $\begin{array}{c}\text { Mo } \\
\text { p.p.m. }\end{array}$ & $\begin{array}{c}\text { Cu } \\
\text { p.p.m. }\end{array}$ \\
\hline \multirow{2}{*}{ 1D59 a } & Farm no. 1 & $2 / 6 / 59$ & 94.8 & 8.34 & 1.7 & 3.3 \\
b & & $16 / 6$ & 93.5 & 8.56 & 1.7 & 3.4 \\
c & Mostly fescue sp. & $1 / 7$ & 92.8 & 7.05 & 1.8 & 2.5 \\
d & Small amounts of & $15 / 7$ & 92.6 & 6.78 & 1.4 & 2.0 \\
e & rumex, timothy & $24 / 8$ & 94.5 & 11.69 & 2.3 & 3.5 \\
f & and clover & $1 / 9$ & 92.9 & 9.87 & 2.5 & 4.9 \\
g & & $19 / 9$ & 93.2 & 13.09 & 2.6 & 3.3 \\
h & & $6 / 10$ & 91.9 & 10.11 & 2.0 & 2.7 \\
\hline \multirow{2}{*}{ 2D59 a } & Farm no. 2 & $3 / 6 / 59$ & 92.9 & 9.57 & 1.9 & 2.9 \\
b & & $16 / 6$ & 93.1 & 7.57 & 1.9 & 2.3 \\
c & Mostly timothy & $6 / 8$ & 90.2 & 11.71 & 1.8 & 3.5 \\
d & Small amounts & $24 / 8$ & 90.6 & 10.64 & 2.1 & 3.2 \\
e & of rumex and & $1 / 9$ & 93.1 & 11.40 & 2.3 & 5.7 \\
f & fescue sp. & $19 / 9$ & 93.1 & 10.68 & 2.7 & 2.7 \\
g & & $6 / 10$ & 92.2 & 11.08 & 1.7 & 2.8 \\
\hline 3D59 a & Farm no. 3 & $2 / 6 / 59$ & 94.7 & 9.02 & 6.8 & 5.2 \\
b & & $17 / 6$ & 93.6 & 8.86 & 2.7 & 3.5 \\
c & & $1 / 7$ & 93.1 & 7.98 & 2.0 & 2.4 \\
d & Mostly fescue sp., & $15 / 7$ & 91.8 & 6.95 & 2.1 & 2.1 \\
e & some carex sp. & $6 / 8$ & 91.8 & 9.02 & 12 & 2.7 \\
f & & $20 / 8$ & 94.0 & 8.99 & 8.1 & 2.7 \\
g & & $3 / 9$ & 93.0 & 9.35 & 17 & 2.8 \\
h & & $6 / 10$ & 92.1 & 7.46 & 5.2 & 2.2 \\
i & & & & & & \\
\hline
\end{tabular}


Table 1 (continued).

\begin{tabular}{|c|c|c|c|c|c|c|c|}
\hline J.no. & & $\begin{array}{c}\text { Farm no. \& } \\
\text { botanical composition }\end{array}$ & $\begin{array}{l}\text { Date of } \\
\text { sampling }\end{array}$ & $\begin{array}{l}\text { Dry matter } \\
\text { per cent }\end{array}$ & $\begin{array}{c}\text { Ash } \\
\text { per cent }\end{array}$ & $\begin{array}{l}\text { Mo } \\
\text { p.p.m. }\end{array}$ & $\begin{array}{c}\mathrm{Cu} \\
\text { p.p.m }\end{array}$ \\
\hline \multirow[t]{8}{*}{$4 \mathrm{D5} 9$} & $\mathbf{a}$ & \multirow{8}{*}{$\begin{array}{l}\text { Different species, } \\
\text { but mostly fescue } \\
\text { and timothy }\end{array}$} & $2 / 6 / 59$ & 94.6 & 11.26 & 28 & 2.8 \\
\hline & d & & $15 / 7$ & 92.5 & 10.27 & 26 & 2.6 \\
\hline & e & & $6 / 8$ & 91.6 & 11.78 & 30 & 3.0 \\
\hline & f & & $6 / 8$ (clover) & ) 90.3 & 12.25 & 18 & 4.9 \\
\hline & g & & $20 / 8$ & 91.0 & 12.01' & 24 & 1.8 \\
\hline & h & & $3 / 9$ & 92.9 & 11.98 & 34 & 3.6 \\
\hline & i & & $17 / 9$ & 93.3 & 11.20 & 17 & 3.4 \\
\hline & j & & $6 / 10$ & 92.7 & 10.45 & 31 & 2.6 \\
\hline \multirow{23}{*}{$\begin{array}{l}\text { 5D59-Tim. } \\
\text {-clov. } \\
\text {-tim. } \\
\text {-clov. } \\
\text {-tim. } \\
\text {-clov. } \\
\text {-tim. } \\
\text {-clov. } \\
\text {-tim. } \\
\text {-clov. } \\
\text {-tim. } \\
\text {-clov. } \\
\text {-tim. }\end{array}$} & $\mathbf{a}$ & \multirow{14}{*}{$\begin{array}{l}\text { Timothy and } \\
\text { clover }(20 \%) \\
\text { New meadow }\end{array}$} & $2 / 6 / 59$ & 91.8 & 11.72 & 4.1 & 4.1 \\
\hline & $\mathbf{a}$ & & $2 / 6$ & 92.9 & 13.81 & 14 & 3.9 \\
\hline & b & & $16 / 6$ & 92.7 & 11.18 & 2.8 & 2.8 \\
\hline & b & & $16 / 6$ & 89.0 & 13.63 & 5.5 & 3.4 \\
\hline & c & & $17 / 7$ & 91.3 & 13.10 & 3.3 & 3.3 \\
\hline & c & & $17 / 7$ & 91.1 & 13.70 & 9.6 & 5.5 \\
\hline & d & & $6 / 8$ & 91.2 & 11.97 & 3.6 & 3.6 \\
\hline & d & & $6 / 8$ & 90.5 & 13.15 & 4.0 & 5.3 \\
\hline & $\mathbf{e}$ & & $20 / 8$ & 89.8 & 11.71 & 8.2 & 3.5 \\
\hline & $\mathbf{e}$ & & $20 / 8$ & 89.0 & 12.82 & 3.9 & 6.4 \\
\hline & f & & $3 / 9$ & 93.0 & 13.36 & 9.4 & 3.3 \\
\hline & $\mathbf{f}$ & & $3 / 9$ & 93.0 & 16.09 & 24 & 9.7 \\
\hline & g & & $17 / 9$ & 92.7 & 13.61 & 8.2 & 3.4 \\
\hline & g & & $17 / 9$ & 92.9 & 12.78 & 23 & 7.7 \\
\hline & $\mathbf{a}$ & \multirow{9}{*}{$\begin{array}{l}\text { Fescue sp. and } \\
\text { timothy }\end{array}$} & $2 / 6 / 59$ & 93.0 & 10.94 & 2.2 & 2.7 \\
\hline & b & & $16 / 6$ & 91.1 & 8.47 & 1.7 & 3.4 \\
\hline & c & & $1 / 7$ & 92.8 & 7.35 & 1.7 & 2.2 \\
\hline & d & & $15 / 7$ & 92.0 & 8.75 & 2.6 & 4.4 \\
\hline & e & & $6 / 8$ & 90.1 & 11.64 & 7.0 & 5.8 \\
\hline & f & & $18 / 8$ & 93.2 & 10.92 & 3.0 & 4.1 \\
\hline & g & & $1 / 9$ & 92.9 & 11.61 & 7.6 & 2.9 \\
\hline & $\mathrm{h}$ & & $19 / 9$ & 92.7 & 11.00 & 3.3 & 2.8 \\
\hline & i & & $6 / 10$ & 92.4 & 9.25 & 2.3 & 2.3 \\
\hline \multirow[t]{9}{*}{ 7D59 } & $\mathbf{a}$ & \multirow[t]{2}{*}{ Farm no. 6} & $3 / 6 / 59$ & 93.1 & 9.27 & 8.3 & 6.5 \\
\hline & b & & $16 / 6$ & 92.8 & 8.90 & 8.0 & 4.5 \\
\hline & c & \multirow{7}{*}{$\begin{array}{l}\text { Mostly fescue and } \\
\text { some carex. } \\
\text { Some other } \\
\text { species }\end{array}$} & $1 / 7$ & 92.6 & 7.97 & 7.2 & 5.6 \\
\hline & d & & $15 / 7$ & 93.2 & 7.37 & 6.6 & 3.7 \\
\hline & $\mathbf{e}$ & & $6 / 8$ & 91.3 & 9.60 & 14 & 5.8 \\
\hline & $\mathbf{f}$ & & $23 / 8$ & 93.3 & 9.78 & 7.8 & 2.9 \\
\hline & g & & $1 / 9$ & 92.7 & 9.27 & 7.4 & 4.6 \\
\hline & h & & $20 / 9$ & 92.4 & 8.59 & 6.0 & 2.6 \\
\hline & i & & $6 / 10$ & 92.4 & 7.07 & 1.8 & 3.5 \\
\hline
\end{tabular}


below the deficiency level of 5 p.p.m., this applying also to the "normal" farm. Though the molybdenum content also showed a general decrease in 1959, it still lies above the dangerous level at 3 p.p.m. on those farms where conditioned copper deficiency is known to occur. A comparison between levels of copper and

Table 2.

Comparison of the molybdenum and copper content of herbage samples in the different years 1957-59.

The values are calculated in oven dried material.

\begin{tabular}{cccccccc}
\hline $\begin{array}{c}\text { Farm } \\
\left.\text { No. }{ }^{1}\right)\end{array}$ & Year & $\begin{array}{c}\text { Date of } \\
\text { sampling }\end{array}$ & $\begin{array}{c}\text { Dry matter } \\
\text { per cent }\end{array}$ & $\begin{array}{c}\text { Ash } \\
\text { per cent }\end{array}$ & $\begin{array}{c}\text { Mo } \\
\text { p.p.m. }\end{array}$ & $\begin{array}{c}\text { Cu } \\
\text { p.p.m. }\end{array}$ & J.no. \\
\hline \multirow{2}{*}{1} & 1958 & $27 / 6$ & 93.9 & 9.10 & 1.7 & 6.4 & 7D58 \\
& 1959 & $16 / 6$ & 93.5 & 8.56 & 1.7 & 3.4 & 1D59b \\
& 1959 & $1 / 7$ & 92.8 & 7.05 & 1.8 & 2.5 & 1D59c \\
2 & 1958 & $27 / 6$ & 92.0 & 8.58 & 1.3 & 2.5 & 4D58 \\
& 1959 & $16 / 7$ & 93.1 & 7.57 & 1.9 & 2.3 & 2D59b \\
3 a & 1957 & $18 / 10$ & & 9.50 & 17 & 3.8 & 1601A \\
& 1958 & $3 / 7$ & 93.9 & 8.52 & 7.7 & 6.0 & $34 D 58$ \\
& 1959 & $1 / 7$ & 93.1 & 7.98 & 2.0 & 2.4 & 3D59c \\
& 1959 & $6 / 10$ & 92.1 & 7.46 & 5.2 & 2.2 & 3D59i \\
3 b & 1958 & $3 / 7$ & 94.4 & 9.81 & 15 & 3.5 & $37 D 58$ \\
& 1959 & $15 / 7$ & 92.5 & 10.27 & 26 & 2.6 & 4D59d \\
6 & 1958 & $20 / 9$ & 91.7 & 12.97 & 13 & 9.1 & 78D58 \\
& 1959 & $20 / 9$ & 92.4 & 8.59 & 6.0 & 2.6 & 7D59h \\
\hline
\end{tabular}

1) The farm numbers are the same as in Table 1.

Table 3 .

Seasonal variations of molybdenum and copper. Frequencies. The values are calculated in oven dried material.

\begin{tabular}{lrrrrrrr}
\hline Date of sampling & $\begin{array}{c}\text { No. of } \\
\text { samples }\end{array}$ & $\begin{array}{c}\text { Mean } \\
\text { Mo } \\
\text { p.p.m. }\end{array}$ & $\begin{array}{c}\text { Standard } \\
\text { error of } \\
\text { mean }\end{array}$ & Variation & $\begin{array}{c}\text { Mean } \\
\text { Cu } \\
\text { p.p.m. }\end{array}$ & $\begin{array}{c}\text { Standard } \\
\text { error of } \\
\text { mean }\end{array}$ & Variation \\
\hline $2 / 6-3 / 6$ & 8 & 8.4 & 3.2 & $1.7-28$ & 3.9 & 0.22 & $2.7-6.5$ \\
$16 / 6-17 / 6$ & 7 & 3.5 & 0.91 & $1.7-8.0$ & 3.3 & 0.066 & $2.3-4.5$ \\
$1 / 7$ & 4 & 3.2 & 1.3 & $1.7-7.2$ & 3.2 & 0.66 & $2.2-5.6$ \\
$15 / 7-17 / 7$ & 7 & 7.4 & 3.3 & $1.4-26$ & 3.4 & 0.23 & $2.0-5.5$ \\
$6 / 8$ & 7 & 10.3 & 3.7 & $1.8-30$ & 4.2 & 0.26 & $2.7-5.8$ \\
$18 / 8-20 / 8-23 / 8-24 / 8$ & 8 & 7.4 & 2.6 & $2.1-24$ & 3.5 & 0.23 & $1.8-6.4$ \\
$1 / 9-3 / 9$ & 8 & 13.0 & 4.0 & $2.3-34$ & 4.7 & 0.64 & $2.8-9.7$ \\
$17 / 9-19 / 9-20 / 9$ & 8 & 9.5 & 2.7 & $2.6-23$ & 3.6 & 0.37 & $2.6-7.7$ \\
$6 / 10$ & 6 & 7.3 & 4.8 & $1.7-31$ & 2.7 & 0.036 & $2.2-3.5$ \\
\hline
\end{tabular}


molybdenum in the herbage material collected during 1957, 1958 and 1959 is given in Table 2. Samples compared are from the same field, taken at about the same time in the summer. The relatively low levels of molybdenum and copper found in $\mathbf{1 9 5 9}$ may be explained by the fact that the summer of that year was unusually dry, producing a rather poor vegetation.

Mean values for all samples collected at the same time throughout the 1959 sampling period are presented in Table 3. Based on these values, graphs are drawn, showing the fluctuations of the molybdenum and copper contents in the vegetation during the summer (Figs. $1 \& 2$ ).

Diagrams showing the precipitation measured in two different localities in the valley are given in Figs. 3 and 4. (By courtesy of Meteorologisk Institutt, Oslo, Norway.)

An examination of the curves showing the seasonal variations of molybdenum and copper reveals a smooth rise from the first of July. During August the values decrease. The curves also show a marked decline about the 20th of July. An examination of the precipitation curves reveals that there was a heavy rainfall on the 15th of July. This caused a submersion of the meadows in several places in Setesdalen, and it is reasonable to assume, therefore, that the otherwise unexplained lowering of the mineral content observed about the 20th of July is probably due to a temporary leaching of the soil. The highest values might otherwise have been expected at about that date.

Rainfall is normally relatively low at the beginning of June, increasing gradually during the later part of the summer. The temperature increases smoothly from June to August, which is also the best period of growth. It appears from the diagrams that molybdenum and copper levels of herbage are relatively high in the early summer, probably due to the lush vegetation produced on the damp soil at that time.

The analytical data presented in this paper seem to indicate a fairly good relationship between molybdenum and copper content of herbage and the intensity of growth. Of further interest is the fact that the levels of molybdenum are subjected to fluctuations to a higher degree than is the content of copper. It should be observed, however, that the climatic conditions during the summer of 1959 were abnormal, the temperature being above, and the precipitation below normal. 


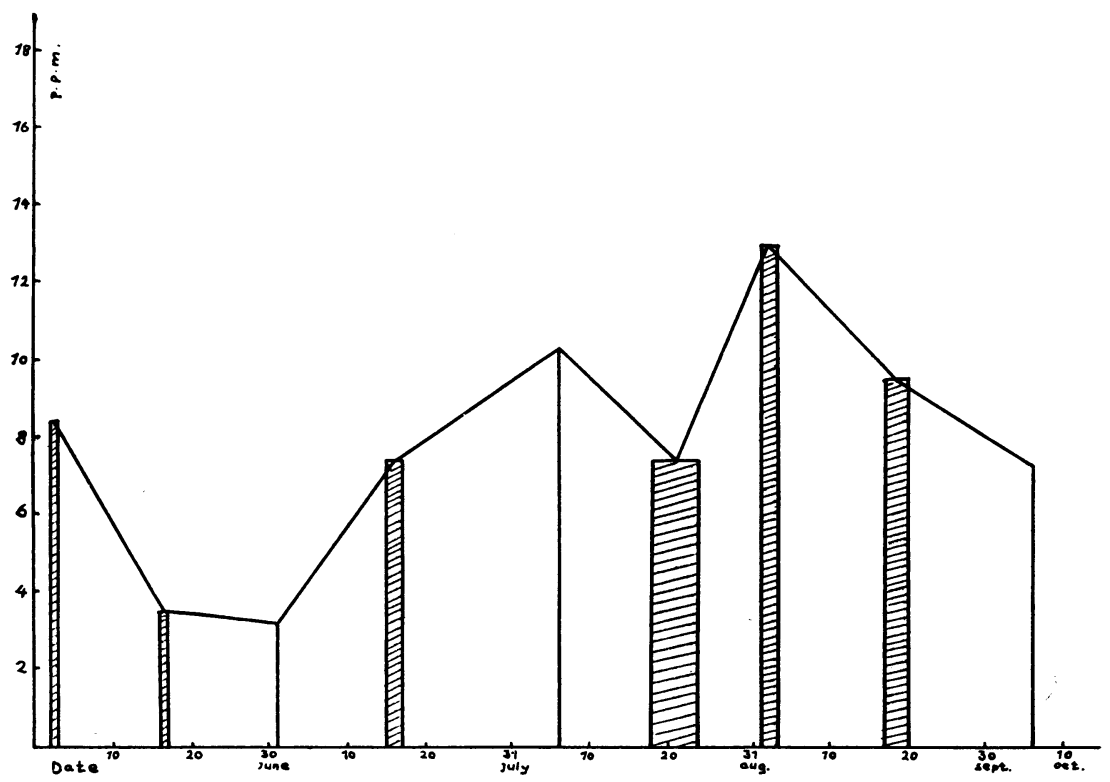

F i g. 1. The seasonal variation of molybdenum in herbage during the summer 1959.

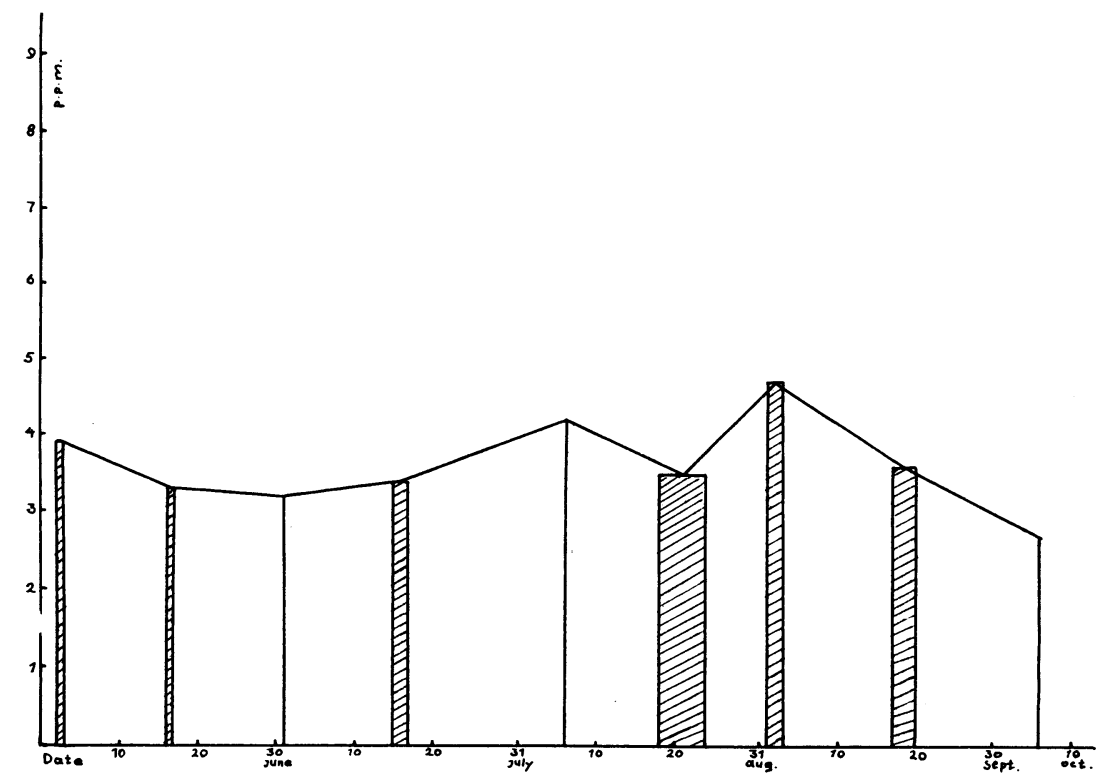

Fig. 2. The seasonal variation of copper in herbage during the summer 1959. 


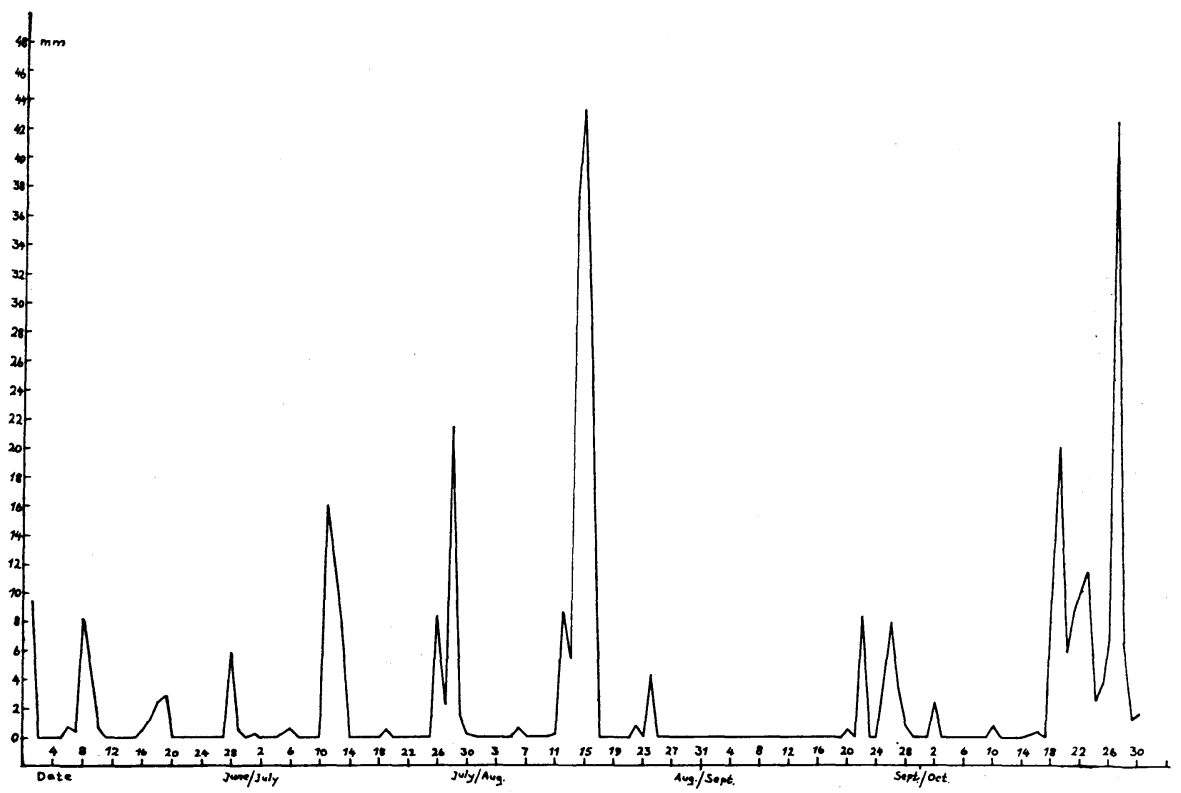

F i g. 3. Precipitation during the summer 1959, measured in Valle, the middle part of Setesdalen (Courtesy of Meteorologisk Institutt, Oslo).

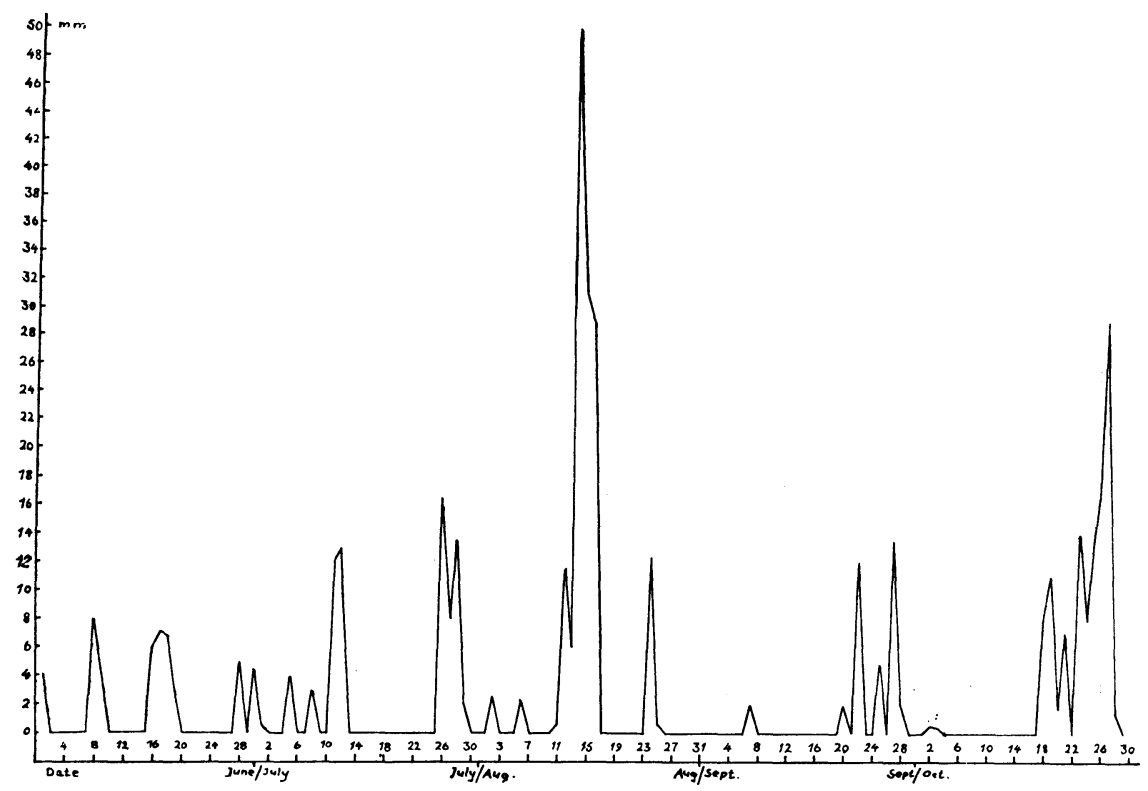

F i g. 4. Precipitation during the summer 1959, measured in Bykle, the northern, higher situated part of Setesdalen (Courtesy of Meteorologisk Institutt, Oslo). 
Consequently, we have not been able to verify Field's results entirely, as he found an inverse relationship between the absorption of molybdenum and copper in the plant during summer time, by which the molybdenum content increased and the copper content decreased. The fact that the maximum content of molybdenum was found later in the summer by this author than by us, may, on the other hand, be due to the different geographtcal locations.

\section{“COMPLETE” SPECTROGRAPHIC ANALYSES OF SELECTED SAMPLES FROM THE 1959 MATERIAL}

The question whether elements other than molybdenum and copper might be of importance in the syndrome of copper deficiency led to the following study:

Ten grass-samples, all of them from the material collected during 1959, were submitted to analyses of, altogether, 18 elements. As the selected samples were all taken at the same time during the summer, a direct comparison could thus be made. The analyses were carried out spectrographically according to the semi-quantitative method described in our previous paper, with the exception of phosphorus and sulphur, which were determined chemically, and potassium, sodium and calcium, which were measured by a flamephotometric procedure. The results are presented in table 4.

\section{Comments on the results}

Lead. All values found seem to be within the normal range.

Tin and cobalt. As the content of these elements is below the limit of detection by the method used, it is impossible to state whether a deficiency is present or not. A toxic amount, however, may be excluded.

Nickel. The content is low, but hardly exceptionally low. Mitchell (1948) states values from 0.5-4.0 p.p.m. as normal, but, in plant material from other localities in Norway, values as low as those from Setesdalen have previously been found.

Manganese. Rather high levels of manganese are found in some samples. Owing to the well known fact that the manganese content in plants may vary to a wide extent, the recorded values cannot be considered as exceptionally high. On acid soils, predominating in Setesdalen, a high manganese content is to be 
Tab l e 4 .

Mineral contents of grassamples collected in the summer 1959.

All values are calculated on the basis of oven dried material.

\begin{tabular}{|c|c|c|c|c|c|c|c|c|c|}
\hline J.no. & & $\begin{array}{l}\text { Date of } \\
\text { sampling }\end{array}$ & $\begin{array}{c}\mathrm{Pb} \\
\text { p.p.m. }\end{array}$ & $\begin{array}{c}\text { Sn } \\
\text { p.p.m. }\end{array}$ & $\begin{array}{c}\text { Mo } \\
\text { p p.m. p }\end{array}$ & $\begin{array}{c}\mathrm{Cu} \\
\text { p.p m. }\end{array}$ & $\begin{array}{c}\text { Co } \\
\text { p.p.m. }\end{array}$ & $\begin{array}{c}\mathrm{Ni} \\
\text { p.p.m. }\end{array}$ & $\begin{array}{c}\text { Mn } \\
\text { p.p.m. }\end{array}$ \\
\hline $1 D 59$ a & & $2 / 6 / 59$ & 1.7 & $<0.85$ & 1.7 & 3.3 & $<0.25$ & 0.75 & 250 \\
\hline $1 D 59 \mathrm{e}$ & $*$ & $24 / 8 / 59$ & 1.7 & $<1.2$ & 2.3 & 3.5 & $<0.35$ & 0.12 & 230 \\
\hline $2 D 59 d$ & & $24 / 8 / 59$ & 1.6 & $<1.1$ & 2.1 & 3.2 & $<0.32$ & 0.11 & 300 \\
\hline $3 D 59$ f & & $20 / 8 / 59$ & 1.8 & $<0.90$ & 8.1 & 2.7 & $<0.27$ & 0.090 & 900 \\
\hline $4 D 59$ a & & $2 / 6 / 59$ & 2.2 & $<1.1$ & 28 & 2.8 & $<0.34$ & 0.11 & 340 \\
\hline $4 \mathrm{D59} \mathrm{g}$ & & $20 / 8 / 59$ & 2.4 & $<1.2$ & 24 & 1.8 & $<0.36$ & 0.36 & 1200 \\
\hline $\begin{array}{c}\text { 5D59 e } \\
\text { tim. }\end{array}$ & & $20 / 8 / 59$ & 2.4 & $<1.2$ & 8.2 & 3.5 & $<0.35$ & 0.055 & 350 \\
\hline $\begin{array}{l}5 \mathrm{D} 59 \mathrm{e} \\
\text { clov. }\end{array}$ & & $20 / 8 / 59$ & 2.6 & $<1.3$ & 3.9 & 6.4 & $<0.39$ & 0.90 & 39 \\
\hline $6 D 59 \mathrm{f}$ & & $18 / 8 / 59$ & 2.2 & $<1.1$ & 3.0 & 4.1 & $<0.33$ & 0.10 & 880 \\
\hline $7 \mathrm{D59} \mathbf{f}$ & & $23 / 8 / 59$ & 2.0 & 0.98 & 7.8 & 2.9 & $<0.29$ & 0.098 & 980 \\
\hline J.no. & & $\begin{array}{c}\text { Date of } \\
\text { sampling }\end{array}$ & $\begin{array}{c}\text { Cr } \\
\text { p.p.m. }\end{array}$ & $\begin{array}{c}\mathrm{V} \\
\text { p.p m. }\end{array}$ & $\begin{array}{c}\text { Sr. } \\
\text { p.p.m. }\end{array}$ & $\begin{array}{c}\text { Ba } \\
\text { p.p.m. } \\
\end{array}$ & $\begin{array}{c}\mathrm{Ti} \\
\text { p.p } \mathrm{m} .\end{array}$ & $\begin{array}{c}\mathrm{Li} \\
\text { p.p m. }\end{array}$ & $\begin{array}{c}\mathrm{Ca} \\
\text { per cent } \\
\end{array}$ \\
\hline $1 D 59$ a & & $2 / 6 / 59$ & 0.085 & $<0.25$ & 8.3 & 13 & 20 & 0.8 & 0.65 \\
\hline $1 D 59$ e & & $24 / 8 / 59$ & 0.11 & 0.35 & 3.5 & 18 & 35 & 0.35 & 0.73 \\
\hline $2 D 59 d$ & & $24 / 8 / 59$ & $<0.11$ & $<0.32$ & 32 & 27 & 27 & 0.53 & 0.56 \\
\hline $3 D 59$ f & & $20 / 8 / 59$ & 0.090 & $<0.27$ & 90 & 23 & 5.9 & 0.60 & 0.42 \\
\hline $4 D 59$ a & & $2 / 6 / 59$ & 0.11 & $<0.34$ & 28 & 7.3 & 4.5 & 0.34 & 0.34 \\
\hline $4 D 59 \mathrm{~g}$ & & $20 / 8 / 59$ & 0.12 & $<0.36$ & 24 & 12 & 9.6 & 0.85 & 0.41 \\
\hline $\begin{array}{c}5 \mathrm{D} 59 \mathrm{e} \\
\text { tim. }\end{array}$ & & $20 / 8 / 59$ & 0.12 & $<0.35$ & 18 & 18 & 3.5 & $<0.12$ & 0.54 \\
\hline $\begin{array}{l}5 \mathrm{D} 59 \text { e } \\
\text { clov. }\end{array}$ & & $20 / 8 / 59$ & $<0.13$ & $<0.39$ & 5.1 & 3.9 & 5.1 & 0.13 & 0.56 \\
\hline $6 \mathrm{D} 59 \mathrm{f}$ & & $18 / 8 / 59$ & 0.10 & $<0.33$ & 22 & 22 & 8.8 & 0.33 & 0.52 \\
\hline $7 D 59 \mathrm{f}$ & & $23 / 8 / 59$ & 0.20 & 0.79 & 100 & 29 & 29 & 9.8 & - \\
\hline J.no. & & $\begin{array}{c}\text { Date of } \\
\text { sampling }\end{array}$ & $\begin{array}{c}\mathrm{Na} \\
\text { per cent }\end{array}$ & $\begin{array}{c}\mathrm{K} \\
\text { per cent }\end{array}$ & $\begin{array}{c}P \\
\text { per cent }\end{array}$ & $\begin{array}{c}\text { Total S } \\
\text { per cent }\end{array}$ & $\begin{array}{l}\text { Sulfat-S } \\
\text { per cent }\end{array}$ & $\begin{array}{c}\text { Dry } \\
\text { matter } \\
\text { per cent }\end{array}$ & $\begin{array}{c}\text { Ash } \\
\text { per cent }\end{array}$ \\
\hline $1 D 59$ a & & & 50 & $x^{-}$ & 0.45 & 0.29 & & & 8.34 \\
\hline $1 D 59$ e & & $24 / 8 / 59$ & 0.163 & 2.46 & 0.49 & 0.36 & 0.15 & 94.5 & 11.69 \\
\hline 2D59 d & & $24 / 8 / 59$ & 0.0249 & 2.87 & 0.40 & 0.26 & 0.076 & 90.6 & 10.64 \\
\hline $3 D 59$ f & & $20 / 8 / 59$ & 0.00894 & $\begin{array}{l}4.19 \\
4\end{array}$ & 0.33 & 0.23 & 0.10 & 94.0 & 8.99 \\
\hline 4D59 a & & $2 / 6 / 59$ & 0.00639 & 2.75 & 0.34 & 0.22 & 0.070 & 94.6 & 11.26 \\
\hline 4D59 g & & $20 / 8 / 59$ & 0.0314 & 2.86 & 0.38 & 0.51 & 0.34 & 91.0 & 12.01 \\
\hline $\begin{array}{c}5 \mathrm{D59} \text { e } \\
\text { tim. }\end{array}$ & & $20 / 8 / 59$ & 0.00548 & 3.27 & 0.33 & 0.23 & 0.072 & 89.8 & 11.71 \\
\hline $\begin{array}{l}5 \text { D59 e } \\
\text { clov. }\end{array}$ & & $20 / 8 / 59$ & 0.0436 & 2.58 & 0.40 & 0.24 & 0.084 & 89.0 & 12.82 \\
\hline $6 \mathrm{D} 59 \mathrm{f}$ & & 10/07 & 0.0191 & 3.03 & 0.38 & 0.30 & 0.12 & 93.2 & 10.92 \\
\hline $7 D 59$ f & & $23 / 8 / 59$ & 0.0202 & 3.15 & 0.38 & 0.29 & 0.099 & 93.3 & 9.78 \\
\hline
\end{tabular}


expected. Mitchell states a variation range of $20-300$ p.p.m. In sample no. 5-D-59-e-clov., originating from a limed soil, the manganese content is fairly low. The timothy sample from the same field (5-D-59-e-tim.) contains a higher amount of manganese. The question of a possible influence of manganese in the copper deficiency syndrome is discussed in detail below.

Chromium. The content of this element seems to be fairly normal. Mitchell states values from $0.1-0.5$ p.p.m.

Vanadium. The content may be on the lower side of the normal. Mitchell states $0.3-0.7$ p.p.m. as normal.

Strontium. In some samples the content seems to be fairly high, as in Norwegian herbage analyses previously carried out, values above 15 p.p.m. have never been found by us. Owing to the limited number of determinations of strontium in Norwegian herbage material, it is difficult to state with certainty if any of the values given in table 4 are exceptionally high.

Barium. The content seems to lie within the normal range. Mitchell reports values from $10-220$ p.p.m.

Lithium. The content seems to be normal compared with previous analyses carried out on Norwegian herbage material. Mitchell reports values varying from $0.05-0.15$ p.p.m.

Calcium. It seems unlikely that a deficiency of calcium is present in this material. Different authors state values ranging from $0.17-0.70 \%$. A great number of determinations carried out by us on Norwegian grass material, collected during a period from the end of June to the beginning of July, gave a mean value of $0.65 \%(0.17-1.80 \%)$.

Sodium. The content of sodium is remarkably low, except for the two "normal" samples: 1-D-59-a and 1-D-59-e. Odén and Wijkström (1935) report values ranging from $0.0046-0.36 \%$, with $0.055 \%$ as a mean, as the normal sodium content in hay. Determinations carried out by us on a great Norwegian grass material, collected during a period from the last part of June to the beginning of July, rendered a mean of $0.037 \%(0.0020-$ $0.42 \%)$. The question whether the sodium level may be of any significance in the copper deficiency syndrome is discussed below.

Potassium. The content looks fairly normal. Odén and Wijkström report values varying from $0.33-1.85 \%$ with a mean of $0.91 \%$ as normal for hay. On a large amount of Norwegian grass 


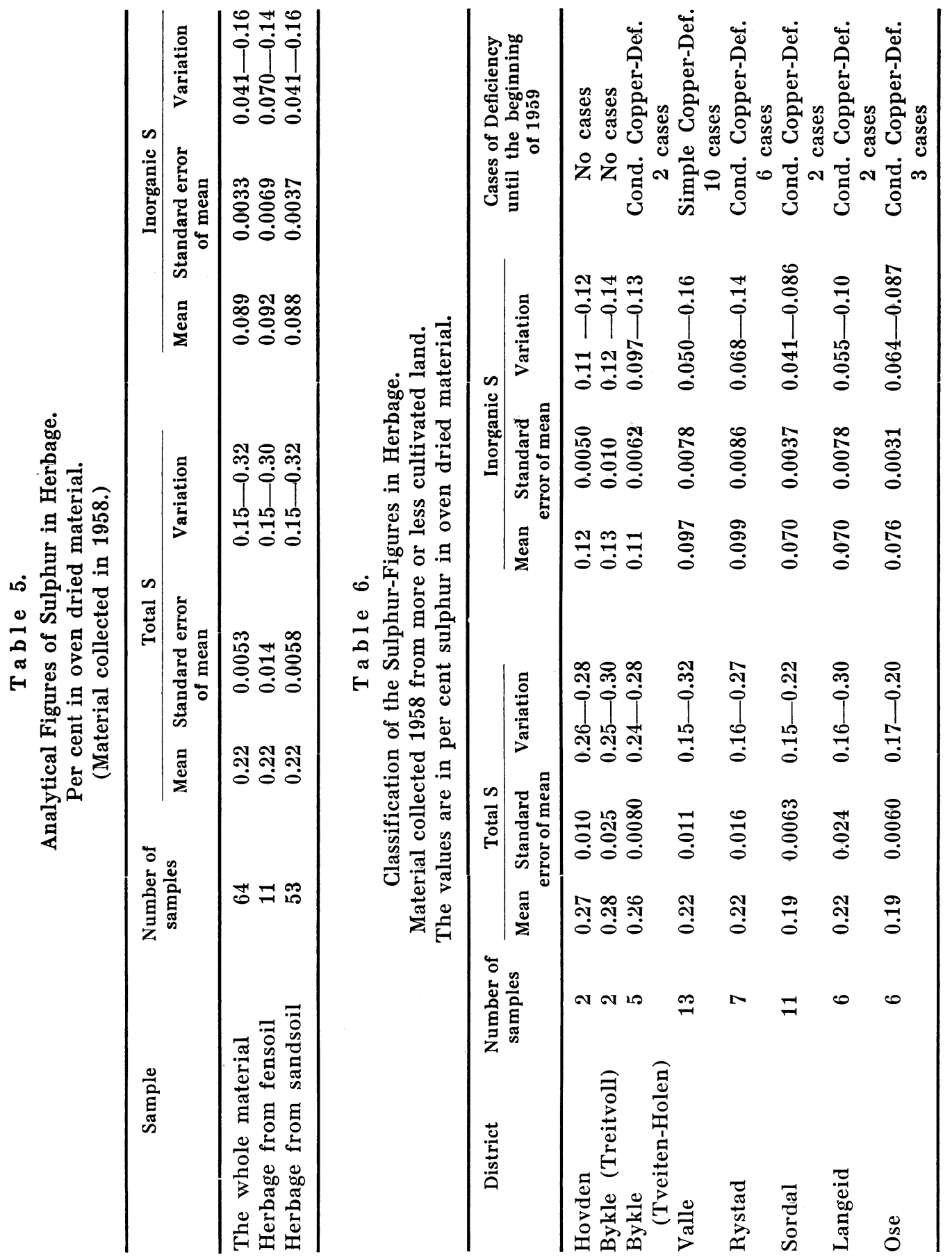


material, collected in the last part of June to the beginning of July, a mean of $2.46 \%(1.16-4.80 \%)$ was found in our laboratory.

Phosphorus. The figures for phosphorus do not indicate a deficiency compared with previous analyses of Norwegian herbage material where a content of about $0.3-0.4 \% \mathrm{P}$ is regarded as normal for pasture. The importance of phosphorus in connection with the copper deficiency syndrome is discussed below.

\section{CONTENT OF SULPHUR IN HERBAGE MATERIAL}

Sulphur has, according to various workers, been stated to be of general importance in the copper deficiency syndrome. Dick $(1952 \& 1953)$ has in his pionering work discussed the question whether sulphur may be a necessary conditioning factor besides molybdenum in the syndrome of conditioned copper deficiency. Through his thorough investigations in this field, he reached the conclusion that a certain level of sulphur is necessary, besides the molybdenum, to lower the copper resorption of the animals.

Owing to these facts, it was decided to submit the whole herbage material from 1958 to analyses of both the total sulphur content and the content of inorganic sulphur (sulphate). The results are presented in Table 5.

The samples in Table 5 are divided into sand soil vegetation and fen soil vegetation. There seems, however, to be no significant difference between the two types of soil with respect to the sulphur status of the vegetation.

A classification of the analytical sulphur values related to the various districts in Setesdalen has been made in Table 6. As stated before (Havre \& al., 1960), a significant difference in the molybdenum and copper levels in herbage was found between districts with conditioned copper deficiency and the district of Valle where simple copper deficiency occurred. With respect to sulphur, the content of this element was slightly higher in the districts above Valle (Bykle, Hovden), but in fact, the conditioned copper deficiency is more widely distributed in districts farther down in the valley than Valle. (Tests of significance are not carried out.) The sulphur content of grass from farms where no cases of copper deficiency were observed in 1958, is presented in Table 7. The table shows that the sulphur content varies to a certain extent, but as a mean it is not lower than the sulphur 
Table 7.

The Content of Sulphur in Herbage from Farms not affected with Hypocuprosis. Material collected in 1958.

(The values are based on oven dried material.)

\begin{tabular}{cccc}
\hline $\begin{array}{c}\text { Farm } \\
\text { no }{ }^{1}\end{array}$ & $\begin{array}{c}\text { Per cent } \\
\text { total S }\end{array}$ & $\begin{array}{c}\text { Per cent } \\
\text { inorganic S }\end{array}$ & District \\
\hline 1 & 0.21 & 0.13 & Valle \\
& 0.18 & 0.063 & \\
3 & 0.32 & 0.15 & $"$ \\
4 & 0.30 & 0.16 & $"$ \\
5 & 0.22 & 0.086 & $"$ \\
& 0.23 & 0.10 & Bykle \\
6 & 0.25 & 0.14 & \\
\hline
\end{tabular}

1) The farm numbers are the same as in Table 4, paper $I$. (Havre \& al., 1960).

content in grass from the typical districts of conditioned copper deficiency, rather the opposite.

Normal values for total sulphur in hay varies, according to Odén and Wijkström (1935), from $0.10-0.28 \%$, with a mean value of $0.19 \%$. Analyses carried out at our institute give as a mean $0.25 \%$ total sulphur for a rather normal pasture, and $0.054 \%$ as a mean for inorganic sulphur in the same pasture. It must be admitted, however, that our material with respect to the sulphur status in the vegetation under Norwegian conditions is not very extensive.

Dick (1953) concluded from his feeding experiments with Lucerne hay to dairy cattle that a daily intake of $2 \mathrm{~g}$ sulphate based on a content of $0.3 \%$ sulphate in the hay, was able to lower the copper resorption already by an intake of $0.5 \mathrm{mg}$ molybdenum per day. $0.3 \%$ sulphate corresponds to $0.1 \%$ inorganic sulphur.

From the analytical data in the present paper, it is not possible to judge whether sulphur plays an important part in the syndrome of conditioned copper deficiency in Setesdalen or not.

\section{COPPER VALUES IN BLOOD SERUM AND LIVER}

Analyses of blood serum revealed copper levels as low as $71 \mu \mathrm{g}$ copper per $100 \mathrm{ml}$. and molybdenum levels up to $24 \mu \mathrm{g}$ per $100 \mathrm{ml}$. in cases of conditioned copper deficiency. It needs to be 
stressed that the copper content of serum, however, is not always regarded as a reliable diagnostic factor (Eden 1941, Loosmore and Allcroft 1951, Allcroft 1952, Van der Grift 1955, Walsh 1951-52).

A few analyses of liver, altogether 5 samples from ewes suspected of suffering from copper deficiency, revealed copper values as low as 29 p.p.m., calculated on dry matter basis. This is significantly below the normal. Underwood (1956), for instance, states liver copper values of about 237 p.p.m. as normal for adult sheep.

Further work concerning the mineral content of blood and liver is proceeding with a view to collecting more comprehensive material.

\section{CLINICAL OBSERVATIONS}

The number of cases of simple copper deficiency, reported in the first paper, was too small for a study of the seasonal variations of this disorder. Since the termination of our first study, however, eleven more cases of simple copper deficiency have been proved and treated in Setesdalen. These cases were distributed over the following months: Two cases occurred in January, one in February, two in March, two in April, two in May and two in the first part of June. Of the ten cases described in the first paper, one occurred in October, one in November, four in January, two in February, one in March and one in April. All cases of simple copper deficiency thus occurred in a period from October to June. From this study it will be seen that the conditioned form of copper deficiency in Setesdalen is prevailing in the autumn, as a disease of pasture, whereas simple copper deficiency is a disease occurring during stallfeeding.

Additional cases of conditioned copper deficiency (altogether eight) were observed in Setesdalen in 1959. Most of these incidences were found in places where the disorder had never been observed before, and where copper dosing, as a consequence, had never been introduced. These farms are all located high up on the hillside, where the soil as a rule is more arid than in the bottom of the valley. The summer of 1959 was extremely dry and herbage analyses revealed that the content of molybdenum and copper was lower in 1959 than in the preceeding two years. It thus appears as if a lowering of the copper contents is of a greater importance in developing the disease than is a corre- 
sponding percentual increase of the molybdenum content, provided this is above the dangerous level.

On the farms sampled in 1959, one case of conditioned and one case of simple copper deficiency were observed during the year. The two farmers, however, had not dosed the animals regularly with copper. It is now the practice in Setesdalen that animals on farms in the exposed areas are copper-dosed monthly.

As mentioned in the previous paper, skeleton disturbances, as described by other authors, have never been observed in connection with copper deficiency in Setesdalen. It seems pertinent, however, to mention a special kind of bone disease occurring on one farm. In the past $6-7$ years, all young animals on this farm, aged from 6 months and upwards, developed upright pasterns with knuckling over of the fetlock and thickening around the fetlock joints. Otherwise the animals were healthy and grew well. The disease defied ordinary treatment with vitamin D, calciumphosphate etc. Analyses revealed that the copper content in hay and grass from this farm was extremely low, 2.3 p.p.m. Copper dosing of the animals had a beneficial effect but did not result in complete recovery. A combination of copper and manganese, however, cured the animals entirely. Analyses of two herbage samples, consisting mainly of timothy, from this farm, one from 1958 and one from 1959, showed a manganese content of 20 p.p.m. in both samples. This value is on the lower side of what is normally found, and is markedly lower than what is found elsewhere in Setesdalen. It must be stressed, however, that this farmer, as one of the few in Setesdalen, is dressing and liming the soil regularly, so that the soil on this farm may be expected to be alkaline. An alkaline soil will markedly reduce the manganese uptake by herbage.

Grashuis \& al. (1953) have described as manganese deficiency a disease occurring among Holstein-Frisian heifers. The disease is characterized by symptoms very similar to the symptoms of copper deficiency. On pastures the animals were unthrifty and grew badly, developing straight hocks and upright pasterns and sometimes with knuckling over of the fetlocks. During stallfeeding in winter time the heifers recovered.

Clinical studies made in another district of Norwey seem to confirm the observation that manganese plays an important role in development of skeleton disturbances in cattle in connection with copper deficiency. The work on this problem is proceeding. 
On one of the farms in Setesdalen (no. 4) where cattle, due to high levels of molybdenum and low levels of copper in herbage, were suffering from conditioned copper deficiency, the owner also had a sheep-stock totalling about 30 animals. During the winter of $1959-60$, the animals were regularly dosed with $5 \mathrm{~g}$ $10 \%$ solution of copper sulphate every month. Lambing took place in May, and all lambs were born healthy. After a couple of days, however, the lambs began to ail and two of them became so weak that they were capable neither of rising nor eating and, therefore, had to be forcibly fed. After injection of $3 \mathrm{ml}$. of a vitamin A- and D-solution, containing 90000 I U of vitamin A and $18000 \mathrm{I} U$ of vitamin $D$, the lambs recovered quickly, but most of them had recidives after another couple of days. A second injection caused a new recovery, but seven lambs still had recidives, two of them with symptoms of swayback. Perorally copper treatment was now tried, with 3-4 drops of a $10 \%$ copper sulphate solution daily for a period of $4-5$ days, repeated after 8 days. All the lambs, except one, recovered and grew up normally.

\section{DISCUSSION}

The aim of the present work is to contribute to a further elucidation of the various conditioning factors involved in the complicated copper deficiency problem.

The fact that molybdenum is an important conditioning factor was established in a previous paper (Havre \& al., 1960). In order to gain further support for the theory, an examination of the seasonal variations of the content of molybdenum and copper in the vegetation was carried out. It was to be expected that the highest molybdenum values in the vegetation was to be found at the same time as, or immediately before the highest frequency of the disorder. According to the observation published in the previous paper, conditioned copper deficiency is a typical autumnal disease, occurring on pasture, and with its highest frequency in November. When other disposing factors, e.g. pregnancy, are taken into account, the correspondence between the seasonal variations of molybdenum in the grass and the outbreak of the disease is fairly good.

As mentioned before, conditioned copper deficiency was in 1959 proved in places where it had never been observed before. These are the higher situated, arid places in the valley. In the 
same year it was also necessary to increase the dosing on those farms where the animals were copper-dosed regularly in order to keep them thriving fully. Furthermore, the results of the analyses revealed that the molybdenum as well as the copper content was as a rule lower in 1959 than in the two previous years, most probably due to the extremely dry summer of this year. All these results seem to point to the fact that a lowering of the copper content in the grass is more important for the development of the disorder than is a corresponding percentage increase of the molybdenum content provided this is still above the dangerous level of 3 p.p.m.

From the clinical studies of simple copper deficiency it is evident that this disorder only occurs during stallfeeding. The curve of the seasonal variations of copper reveals that the vegetation has its lowest copper content around the 1st of July which is the time of grass-mowing in Setesdalen. As the winterfeeding consists almost entirely of home produced hay, the conditions may be favourable for the simple copper deficiency to develop in the winter time.

The study of the seasonal variations also reveals that the copper content of the vegetation in areas exposed to simple copper deficiency during the whole sampling period actually lies below the deficiency level of 5 p.p.m. Anyway this applies to the extreme year 1959. As the animals, despite this low copper content, keep healthy on pasture throughout the summer, it may be reasonable to assume that the grass in this period contains a factor influencing the copper metabolism in a favourable direction. Moreover, the occurrence of simple copper deficiency is not equally frequent throughout the year, but is most prevalent in the late winter. This fact may be explained by the low copper content in the hay, mowed when the copper content in the grass is lowest. If, in addition, the above mentioned "copper favouring factor" is taken into account, and it is assumed that this "factor" does not stand a longer time of storing and consequently is wasted during the winter, the fact seems still more reasonable.

With respect to the conditioned copper deficiency, most authors agree that molybdenum influences the copper metabolism in an unfavourable direction, which is also verified by our own investigations, but the mechanism of this influence is still obscure. Practical experience has made it evident that when a cow is moved from a pasture with a low copper level to a pasture 
with a high molybdenum level, the animal will develop conditioned copper deficiency within a very short time, provided the transferance takes place in the "right period". Consequently, the molybdenum does not require a long time to manifest its effect, provided the conditions are otherwise favourable. The analytical results in Table 1 reveal furthermore that on farms exposed to conditioned copper deficiency in 1959 (farm no 3-6), the copper content of the vegetation was below the deficiency level, though higher than what was found for herbage from areas exposed to simple copper deficiency (farm no 2). Already by about 15th July, the molybdenum content was high enough to produce favourable conditions for the disorder, but nevertheless the outbreak was delayed until August. This delay may, of course, have several reasons, but it seems improbable that a high copper reserve should be present in the animals, as the copper content of the herbage was so low. The above mentioned hypothetical "copper favouring factor" may, however, explain a lot.

It was observed (on farm no 4) that injections of vitamin A and $D$ had a beneficial effect on lambs suffering from copper deficiency. Obviously, the copper dosing on this farm in the year 1959 had been insufficient, which was also the case on several other farms in Setesdalen that year. Other practical experiences also suggest that vitamin A may be a "copper favouring factor", although we are naturally aware of the fact that vitamin $A$ also has a "general" beneficial effect on the organism.

It should be strongly emphasized that this "copper favouring factor" is still of a purely hypothetical nature, and further investigations are needed to solve this problem.

In order to examine whether other conditioning factors, besides molybdenum, may be present in the syndrome of conditioned copper deficiency, a series of analyses was carried out of a number of elements in a limited number of herbage samples, collected during the summer of 1959 . Special attention was paid to sulphur, and this element was analysed in the whole material collected in 1958. From the analytical results obtained, however, it is impossible to state whether sulphur may have any effect on the copper deficiency complex in Setesdalen.

Of the other elements, attention may be paid to sodium. Samples from farms with either form of copper deficiency showed a low content of this element compared with the "normal" farm. In the first paper it was mentioned that diarrhoea in connection 
with copper deficiency may be induced by reducing the water supply, and it seems reasonable to suppose that a low sodium content in the fodder will reduce the water absorption by which the symptoms of conditioned copper deficiency are more easily induced. (In Setesdalen, salt is rarely added to the fodder.) It may be noticed that in Setesdalen a pruritus, curable with salt doses, has been observed in horses.

With respect to bone disorders, or skeleton disturbances, in connection with copper deficiency, it is obvious that calcium and phosphorus must play a role, and manganese may also be important. The calcium and phosphorus values in Table 4 reveal a favourable Ca/P-ratio, namely 1.3 as a mean. With respect to phosphorus, the mean value calculated from table 4 is $0.39 \% \mathrm{P}$. Walsh \& al. (1951—52), describing conditioned copper deficiency in ruminants along with rickets in foals, have found a mean value of $0.16 \% \mathrm{P}$ in the fodder, and a mean Ca/P-ratio of 4.5 . This may explain, to a certain extent anyway, why skeleton disturbances have never been observed in connection with copper deficiency in Setesdalen. However, beneficial results of combined therapy with copper and manganese to cattle with bone disorders on a farm in Setesdalen is previously reported in this paper. Unthriftiness in the sheep on the same farm has also been treated in a favourable way by copper therapy. The possible role of manganese in the copper deficiency syndrome, however, is still obscure, but it is hoped that further investigations will reveal new facts.

\section{ANALYTICAL PROCEDURES}

The spectrographic determinations were carried out according to the procedure described in a previous paper (Havre \& al., 1960 ).

The determination of sodium, potassium and calcium was carried out by a flame-photometric procedure (Havre, 1961).

The determination of total-sulphur was carried out chemically by oxidising the sulphur in the grass with sodium-peroxide, according to Wijkström (1935).

Inorganic sulphur (sulphate) was extracted from the grasspowder with hydrochloric acid $(2: 5)$, and the sulphate in the extract precipitated with barium chloride.

All analytical values are calculated on the basis of material dried in oven for eighteen hours at $80^{\circ} \mathrm{C}$. 


\section{ACKNOWLEDGEMENT}

The authors wish to express their sincere thanks to The Agricultural Research Council of Norway for financial support, and to Professor Fredr. Ender for helpful discussions and for his interest in this work.

\section{REFERENCES}

1. Allcroft, R.: Vet. Rec. 1952, 64, 17.

2. Cunningham, I. J.: Advances in Vet. Sci. 1955, 2, 138.

3. Dick, A. T.: Austr. Vet. J. 1952, 28, 30.

4. Dick, A. T.: Ibid 1953, 29, 18.

5. Dick, A. T.: Ibid 1953, 29, 233.

6. Eden, A.: J. Agric. Sci. 1941, 31, 186.

7. Field, H. I.: Vet. Rec. 1957, 69, 832.

8. Grashuis, J., Lehr, J. J., Beuvery, L. L. E. and Beuvery-Asman, A.: Mangaandeficiëntie bij rundvee. Inst. Moderne Veevoeding "De Schothorst" 1953.

9. Havre, G. N.: Anal. Chim. Acta, 1961. In press.

10. Havre, G. N., Dynna, O. and Ender, F.: Acta vet. scand. 1960, 1, 250.

11. Loosmore, R. M. and Allcroft, R.: Vet. Rec. 1951, 63, 414.

12. Mitchell, R. L.: Technical Communication No 44, 1948. Commonwealth Bureau of Soil Science, England.

13. Odén, S. and Wijkström, T.: Meddelande nr. 453 från Centralanstalten för försöksväsendet på jordbruksområdet. Stockholm 1935.

14. Underwood, E. J.: Trace Elements in Human and Animal Nutrition 1956, p. 64.

15. Van der Grift, J.: Versl. Landbouwk. Onderz. No 61.10, s'Gravenhage. 1955.

16. Walsh, T., Neeman, M. and O'Moore, L. B.: J. Dept. Agric., Eire $1951-52,48,32$.

17. Wijkström, T.: Meddelande nr. 459 från Centralanstalten för försöksväsendet på jordbruksområdet. Stockholm 1935.

\section{SUMMARY}

The present paper is the continuation of a previously published work, (Havre \& al., 1960), on the study on conditioned and simple copper deficiency in cattle and sheep in Setesdalen, a valley in the South of Norway.

In order to verify molybdenum as a conditioning factor, the fluctuations of the content of molybdenum and copper in the grass during the summer season 1959 have been studied. It was found that the content of both molybdenum and copper increased during the summer and reached its highest values in the first part of August. As stated in the previous paper, the conditioned copper deficiency in Setesdalen was proved to be a disorder occurring on autumnal pasture. 
From the clinical material collected during the years 1958-60, it may be concluded that the simple copper deficiency in Setesdalen occurs only in the winter. season, on stallfeeding. This corresponds fairly well with the fact that the copper content of the herbage has its lowest value about the first of July, the time for grass-mowing in Setesdalen.

The seasonal variations of copper and molybdenum were compared with statistics of the precipitation in the investigated areas in the same summer. The content of molybdenum as well as copper in grass was found to be lower in 1959 than in the previous years, probably due to the dry summer in 1959. The molybdenum figures, however, are still above 3 p.p.m. in herbage from areas with conditioned copper deficiency, and the copper figures below 5 p.p.m. in areas with simple copper deficiency. These concentrations were in the first work, in accordance with Cunningham, stated as the "dangerous" limits.

In the present work, spectrographic analyses of a series of elements, altogether 18, are carried out on grass samples collected in the summer of 1959. The etiological importance of the various elements is discussed and particular attention is paid to sodium, manganese and sulphur. Sulphur is treated more thoroughly, as the whole herbage material from 1958 has been analysed on total as well as on inorganic sulphur (sulphate), in order to study Dick's theory on sulphur as a conditioning factor in the syndrome of conditioned copper deficiency. The results of the analyses, however, give no support for sulphur as a conditioning factor in Setesdalen.

A hypothetical "copper favouring factor", possibly vitamin A, is discussed.

The clinical observations are discussed in relation to the analytical results.

\section{ZUSAMMENFASSUNG}

Vorkommen bedingten und einfachen Kupfermangels beim Rind und Schaf im Setesdal, einem Tal in Südnorwegen. II.

Der vorliegende Artikel bildet die Fortsetzung einer früher veröffentlichten Arbeit über das Vorkommen bedingten und einfachen Kupfermangels im Setesdal (Havre \& al., 1960).

Diese Fortsetzung bezweckte, durch Untersuchung der Variationen im Gehalt der Vegetation an Molybdän und Kupfer während der ganzen Sommersaison 1959 die Wirkung des Molybdäns als bedingenden Faktors zu bestätigen. Es wurde festgestellt, dass der Gehalt sowohl an Molybdän als auch Kupfer im Laufe des Sommers anstieg und seinen Höhepunkt im ersten Teil des Monats August erreichte. Die bedingende Form von Kupfermangel im Setesdal erwies sich in der vorhergehenden Arbeit als eine Weidekrankheit auf der Herbstweide.

Das aus den Jahren 1958-60 gesammelte klinische Material hat gezeigt, dass einfacher Kupfermangel ausschliesslich bei Stallfütterung im Winterhalbjahr vorkommt. Dies stimmt gut damit überein, dass 
der Kupfergehalt der Vegetation seine niedrigsten Werte zur Zeit der Ernte um den 1. Juli herum gezeigt hat. Die Kurven für die Molybdänund Kupfervariationen im Gras wurden ebenfalls mit einer Niederschlagsstatistik für die untersuchten Gebiete im gleichen Sommer verglichen.

Es hat sich gezeigt, dass die gefundenen Werte für Gras sowohl in bezug auf Molybdän als auch Kupfer in dieser Saison niedriger als in den Jahren vorher lagen, was vermutlich dem trockenen Sommer im Jahre 1959 zuzuschreiben ist. Die Werte lagen jedoch fernerhin über 3 p.p.m. Molybdän in Gegenden mit bedingtem Kupfermangel und unter 5 p.p.m. in Gebieten mit einfachem Kupfermangel. Diese Konzentrationen wurden in der vorigen Arbeit, in Uebereinstimmung mit Cunningham, als die ,gefährlichen“ Grenzen charakterisiert.

In den vorliegenden Untersuchungen wurden auch spektrographische Analysen einer Reihe von Elementen, insgesamt 18, in Gras ausgeführt, das im Sommer 1959 eingesammelt worden war. Die Bedeutung der verschiedenen Elemente in Beziehung zum Vorkommen des Kupfermangelsyndroms wird erörtert, und die Aufmerksamkeit besonders auf Natrium, Mangan und Schwefel gerichtet. Schwefel wurde insofern eingehender behandelt, als das ganze im Sommer 1958 eingesammelte Vegetationsmaterial sowohl auf Totalschwefel als auch anorganischen Schwefel (Sulfat) analysiert wurde; dies geschah, um Dicks Theorie über den Schwefel als bedingenden Faktor bei dem bedingten Kupfermangel durch Versuch zu bestätigen. Die Resultate der Analysen liefern jedoch keine direkte Stütze dafür, dass Schwefel unter den im Setesdal herrschenden Verhältnissen bedingend wirkt.

Ein hypothetischer „kupferfreundlicher Faktor“, möglicherweise Vitamin A, wird erörtert.

Die klinischen Beobachtungen werden in Relation zu den analytischen Ergebnissen diskutiert.

\section{SAMMENDRAG}

Forekomst av betinget og enkel koppermangel hos storfe og sau $i$ Setesdalen, en dal i Syd-Norge. II.

Den foreliggende artikkel er en fortsettelse av et tidligere publisert arbeid om forekomsten av betinget og enkel koppermangel i Setesdalen (Havre \& al., 1960).

Det nærværende arbeid har gått ut på å verifisere molybdenets virkning som en betingende faktor ved å unders $\varnothing$ ke svingningene i vegetasjonens innhold av molybden og kopper gjennom sommersesongen 1959. Det ble konstatert at innholdet av både molybden og kopper steg utover sommeren, og nådde sitt høydepunkt i første del av august. Den betingede form for koppermangel $i$ Setesdalen ble $i$ forrige arbeid vist å være en beitesykdom på høstbeite.

Det samlede kliniske materiale fra årene 1958-60 har vist at den enkle koppermangel utelukkende forekommer på inneforing i vinterhalvåret. Dette korresponderer bra med at kopperinnholdet $i$ vegetasjonen viser seg å ha sin laveste verdi ved slåttetider omkring 1. juli. 
Kurvene over molybden- og koppervariasjonene i gras ble også sammenholdt med en nedbørsstatistikk for de unders $\not k t e$ områder samme sommer.

Det har vist seg at de fundne verdier $\mathrm{i}$ gras for såvel molybden som kopper, i denne sesong lå lavere enn årene før, hvilket antakelig skyldes den tørre sommer i 1959. Verdiene lå imidlertid fremdeles over 3 p.p.m. molybden i områder med betinget koppermangel, og under 5 p.p.m. kopper i områder med enkel.koppermangel. Disse konsentrasjoner ble i forrige arbeid, i overensstemmelse med Cunningham, karakterisert som de „farlige“ grenser.

I det foreliggende arbeid er også utført spektrografiske analyser av en serie elementer, tilsammen 18, i gras som ble samlet inn sommeren 1959. Betydningen av de forskjellige elementer $i$ relasjon til forekomst av koppermangel-syndromet er drøftet, og oppmerksomheten rettes særlig mot natrium, mangan og svovel. Svovel er behandlet mer inngående, idet hele vegetasjonsmaterialet som ble samlet inn sommeren 1958 er analysert på både total-svovel og uorganisk svovel (sulfat); dette for å fors $\phi k$ å verifisere Dick's teori om svovel som en betingende faktor ved den betingete koppermangel. Analyseresultatene gir imidlertid ingen direkte st $\varnothing$ tte for at svovel virker betingende under de rådende forhold i Setesdalen. droftet.

En hypotetisk „koppervennlig faktor“, muligens vitamin A, er

De kliniske observasjoner er drøftet $i$ relation til de analytiske resultater.

(Received September 29. 1961). 